\title{
The Relationship between Liquidity Risk and Failure of Commercial Banks in Kenya
}

\author{
Ogilo Fredrick ${ }^{1, *}$, Omwoyo Jeremiah ${ }^{2}$, Zipporah Onsomu ${ }^{3}$ \\ ${ }^{1}$ Lecturer, School of Business, University of Nairobi, Kenya \\ ${ }^{2}$ MBA Student, University of Nairobi, Kenya \\ ${ }^{3}$ Tutorial Fellow, School of Business University of Nairobi, Kenya
}

Copyright $\bigcirc 2018$ by authors, all rights reserved. Authors agree that this article remains permanently open access under the terms of the Creative Commons Attribution License 4.0 International License

\begin{abstract}
This study sought to establish the relationship between liquidity risk and failure of commercial banks in Kenya in the years 2013 to 2016. Additionally, the study endeavoured to establish the effect of capital adequacy, asset quality, management quality, earnings, sensitivity to market and size on the failure of banks in Kenya. To achieve this goal, secondary data was collected from the websites of operational banks while data for failed banks was collected from reports published by the central bank of Kenya, corroborated with publications in past years newspapers. Panel logit regression was used to analyze the data using Eviews 9.5 student version. The results of the regression revealed that there was a positive and significant relationship between liquidity risk and bank failure, implying that liquidity increased the likelihood of failure. The study also found a positive and significant relationship between bank failure and asset quality and earnings indicating that they increased the likelihood of failure. The study found a negative and significant relationship between bank failure and management quality and sensitivity to market implying that they decreased the likelihood of bank failure. Capital adequacy and bank size were found to have insignificant relationship with the failure of commercial banks in Kenya. These findings are valuable to managers in understanding how the variables of the study increase or decrease the likelihood of failure so that they may come up with appropriate strategies for managing the various risks facing their banks
\end{abstract}

Keywords Liquidity Risk, Bank Failure, Capital Adequacy, Bank Size

\section{Introduction}

Banks play an indispensable function in a country's financial system and economy as a whole through offering intermediary and liquidity services (Heffernan, [1]). The function of financial intermediation inherently exposes banks to liquidity risk through the activity of transforming the maturity of short-term liabilities and demand deposits into long term maturity assets in form of loans. Kumar and Yadav [2] explains liquidity as a bank's capacity to fund increase in assets and meet both expected and unexpected cash and collateral obligations at reasonable cost and without incurring unacceptable losses. According to Kaufman [3] a bank is deemed to be a failure if the market price of its assets is diminished to an extent that it is less than the market price of its liabilities. Daley, Matthews and Whitfield [4] contend that bank failure includes closure, bankruptcy, supervised merger, or direct government assistance. Minamihashi [5] consider a bank to be a failure if it suspends issuance of new loans or credit to its clients. According to Bennett and Unal [6] liquidity, undercapitalization, safety, soundness, and fraud are some of the causes of bank failure.

\subsection{Liquidity Risk}

Banks [7] defined liquidity risk as the uncertainty that a bank may incur loss due to a lack of cash or its equivalents or that it may suffer economic loss in its attempt to procure the cash vital for its operations. According to Farag et al. [8] liquidity risk can take two forms: Funding liquidity risk, which results from the bank having insufficient cash and collateral to settle debts owed to counterparties and customers immediately; and market liquidity risk which is the possibility that the bank's assets cannot be cashed quickly without incurring large discounts.

Liquidity is important to banks because it compensates for expected and unexpected fluctuations in their financial position besides providing funds for their growth; also if a bank suffers from a liquidity shock and it fails to repay depositors and other creditors amounts owed to them punctually then it may be declared cash-flow insolvent (Faraget al., [8]).The importance of liquidity risk (both funding and market) is underscored by the fact that it has potential to cause severe liquidity spirals (Gomes \& Khan, [9]).Severe liquidity crisis may arise when numerous 
depositors withdraw their savings at once leaving the bank without funds causing what is known as a bank run. Such bank runs can even cause "healthy" banks to fail affecting the entire economy (Diamond \& Dybvig, [10]). Another reason why liquidity risk is important as observed by Acerbi and Scandolo [11] is that it can explode market and credit risks in addition to transforming loss in one bank into a systemic and contagious crisis.

According to Banks [7] the two most frequently used measures of liquidity risk are liquidity ratios and liquidity gaps. Empirical studies reviewed in this study reveal there is no single measure of liquidity risk that suits all studies. Liquidity coverage ratio and the net stable funding ratio have also been used to quantify liquidity risk by Cucinelli [12]. Ogilo and Mugenyah [13]; and Wekesa [14] adopted the loans to deposits ratio to measure the same. Berger and Bouwman [15]) propounded the comprehensive liquidity measure (BB) which has been used by Fungacova, Turk and Weill [16] and Zheng, Cheung, and Cronje [17]. Liquidity risk is measured in this study by ratio of loans to deposits.

\subsection{Bank Failure}

According to Kaufman [18] a bank is deemed to be a failure if the market price of its assets is diminished to an extent that the market price of its assets is exceeded by that of its liabilities. Bank failure consequences can be financial, economic, and social or even political (Okeahalam, [19]). Additionally, Minamihashi [20] postulate that bank failure affects client firms of failed banks since they cannot borrow from the failed banks causing them to suffer from a credit crunch something that may stagnate the activities of such clients. Müller and Trümpler [21] opine that failure of banks precede a significant drop in output and an upsurge of unemployment. Macey and Miller [22] argue that the government's stake in the financial stability of banks and the fact that many people perceive healthy banks as essential for a stable economy makes bank failure a matter of concern and hence important to study. Another reason why bank failure may warrant a study is the resultant loses. James [23] found out that failed banks lose a substantial value of their assets averaging to about 30\% while bank closure cost averaged to $10 \%$ of the banks' assets.

According to Bouvatier, Brei and Yang [24] bank failure is measured by an indicator or dummy variable which indicates whether an event has or not happened. According to Skrivanek [25] indicator variables are used in regression to assign either " 1 " or " 0 " to members of two mutually exclusive categories. This study measured bank failure according to Zheng, et al. [17] where a binary performance variable was adopted to signify whether a bank fails in a particular financial year. As such a bank that fails within a period of 12 months will be flagged failure and given a score of one, otherwise it is flagged surviving and given a score of zero.

\subsection{Research Objective}

To find out the relationship between liquidity risk and failure of commercial banks in Kenya the period 2013 to 2016.

\subsection{Conceptual Framework}

The conceptual model in figure 1 below shows how the independent variables, the control variable and the dependent variable are related. The dependent variable was measured by the probability of bank failure was measured by either one if a bank fails or zero if it does not fail in a particular year. The independent variable, liquidity risk, is represented by the ratio of liquid assets to customer deposits. The control variables involved the use of bank management techniques which are: capital adequacy, asset quality, management capability, earnings, sensitivity and bank size are included to control for omitted variables error in the regression.

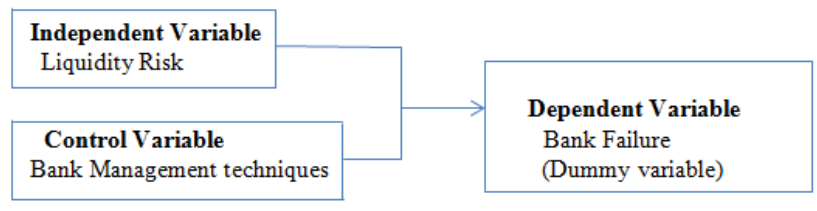

Figure 1. Conceptual framework

\section{Methods}

The study subscribed to a quantitative descriptive research design to investigate if there exist a relationship between liquidity risk and failure of commercial banks in Kenya. The population of the study was all the 43 commercial banks licensed and operating in Kenya on $1^{\text {st }}$ of January 2013. A census study approach was adopted because the total number of banks in Kenya are few compared with other countries such as USA that have thousands of banks at any one point in time. A total of 42 commercial banks, whose accounts had been incorporated in the bank supervision annual report 2012 (CBK, [26]) were included in the study. The study relied on secondary data extracted from the audited annual financial statements and other disclosures of all commercial banks licensed to operate in Kenya as posted in their respective websites or gleaned from the annual bank supervision reports of the central bank of Kenya, for the period 2013 to 2016. The study employed logistic (logit) regression analysis to establish the relationship between bank failure and liquidity risk.

\subsection{Analytical Model}

The analytical model of the study consists of bank failure as the dependent variable and liquidity as the independent variable. However to control for omitted variables regression error, capital adequacy, asset quality, management capability and sensitivity to market and bank size were used as control variables. 
The logit regression model employed to analyze the effect of liquidity risk on bank failure is specified below.

$\operatorname{Prob}($ Bankfailureindicator $=1 \mid X, Z)=\wedge\left(\alpha+\beta_{1} X_{1 i t}+\beta_{2} X_{2 i t}+\beta_{3} X_{3 i t}+\beta_{4} X_{4 i t}+\beta_{5} X_{5 i t}+\beta_{6} X_{6 i t}+\beta_{7} X_{7 i t}\right)$

Where $\wedge(Y)=\frac{e^{Y}}{1+\mathrm{e}^{Y}}=\frac{\exp (Y)}{1+\exp (Y)}, Y=\alpha+\beta_{1} X_{1 i t}+\beta_{2} X_{2 i t}+\beta_{3} X_{3 i t}+\beta_{4} X_{4 i t}+\beta_{5} X_{5 i t}+\beta_{6} X_{6 i t}+\beta_{7} X_{7 i t}+\varepsilon_{i t}$

$$
\operatorname{Orlogit}(p)=\alpha+\alpha+\beta_{1} X_{1 i t}+\beta_{2} X_{2 i t}+\beta_{3} X_{3 i t}+\beta_{4} X_{4 i t}+\beta_{5} X_{5 i t}+\beta_{6} X_{6 i t}+\beta_{7} X_{7 i t}+\varepsilon_{i t}
$$

Where (p) is the probability of bank failure, $\mathrm{Y}$ is the dependent variable bank failure, $\wedge$ is the cumulative logistic distribution function and $\mathrm{X}_{1}, \mathrm{X}_{2}, \ldots \mathrm{X}_{7}$ represent liquidity risk, capital adequacy, asset quality, management efficiency, earnings, sensitivity to market, and bank size respectively. In the model $\alpha$ is the intercept and $\beta_{1}, \beta_{2} \ldots \beta_{7}$ are the respective coefficients of the independent variable and control variables. Lastly, $I$ is the individual bank ranging from 1 to $42, t$ is the time which can range from 1 to 4 and $\mathcal{E}$ is the error term.

\section{Results and Discussion}

\subsection{Correlation Analysis}

As shown on the second column of Table 1 below, the relationship between failure and the explanatory variables was found to be low with the highest being -0.083 for failure and sensitivity to market and the lowest being 0.014 between failure and loan to deposit ratio (LAD). Column 3 of Table 1 shows the correlation between liquidity risk (LAD), and the other explanatory variable. The correlation between liquidity risk capital adequacy, asset quality, management quality, earnings, sensitivity to market and size (ASSETS) to three decimal places are $0.299,-0.352,-0.390,0.248,0.616$, and -0.016 respectively. Capital adequacy has a correlation of $-0.151,-0.132,-0.12,0.185$ and -0.199 with asset quality (AQ), management quality (MQ), earnings (ROA), sensitivity to market (SM), and size (ASSETS) respectively. Asset quality has a correlation of 0.462 with management quality, -0.594 with earnings, -0.262 with sensitivity to market and -0.360 with size. Management quality has a correlation of negative (-) 0.532 with earnings, -0.5 with sensitivity to market, and -0.143 with size. Earnings (ROA) have a correlation of 0.181 with sensitivity to market, and 0.597 with size. Finally, sensitivity to market has a correlation of 0.005 with size.

Table 1. Spearman rank-Order

\begin{tabular}{|c|c|c|c|c|c|c|c|c|}
\hline \multicolumn{9}{|c|}{ Covariance Analysis: Spearman rank-order } \\
\hline \multicolumn{3}{|c|}{ Date: $11 / 02 / 17$ Time: $14: 12$} & & & & & & \\
\hline \multicolumn{2}{|c|}{ Sample: 20132016} & & & & & & & \\
\hline \multicolumn{9}{|c|}{ Included observations: 157} \\
\hline \multicolumn{2}{|c|}{ Correlation } & & & & & & & \\
\hline Probability & FAILURE & LAD & CAR & AQ & MQ & ROE & SM & ASSETS_MILI \\
\hline \multirow{2}{*}{ FAILURE } & 1.000 & & & & & & & \\
\hline & ----- & & & & & & & \\
\hline \multirow{2}{*}{ LAD } & 0.014 & 1.000 & & & & & & \\
\hline & 0.866 & ----- & & & & & & \\
\hline \multirow{2}{*}{ CAR } & 0.038 & 0.299 & 1.000 & & & & & \\
\hline & 0.635 & 0.000 & $\begin{array}{ll}---- \\
-\cdots\end{array}$ & & & & & \\
\hline \multirow{2}{*}{ AQ } & 0.046 & -0.352 & -0.151 & 1.000 & & & & \\
\hline & 0.565 & 0.000 & 0.059 & ----- & & & & \\
\hline \multirow{2}{*}{ MQ } & -0.038 & -0.390 & -0.132 & 0.462 & 1.000 & & & \\
\hline & 0.635 & 0.000 & 0.099 & 0.000 & ----- & & & \\
\hline \multirow{2}{*}{ ROE } & 0.097 & 0.248 & -0.012 & -0.594 & -0.532 & 1.000 & & \\
\hline & 0.228 & 0.002 & 0.878 & 0.000 & 0.000 & ---- & & \\
\hline \multirow{2}{*}{ SM } & -0.083 & 0.616 & 0.185 & -0.262 & -0.500 & 0.181 & 1.000 & \\
\hline & 0.301 & 0.000 & 0.020 & 0.001 & 0.000 & 0.024 & ----- & \\
\hline \multirow{2}{*}{ ASSETS_MILI } & -0.031 & -0.016 & -0.199 & -0.360 & -0.143 & 0.597 & 0.005 & 1.000 \\
\hline & 0.697 & 0.838 & 0.013 & 0.000 & 0.073 & 0.000 & 0.947 & $\begin{array}{l}---- \\
--\end{array}$ \\
\hline
\end{tabular}




\subsection{Regression Analysis}

In order to find how the independent variables explain failure of commercial banks in Kenya over the study period panel logit regression analysis was carried out and the results are shown on Table 2 below.

Table 2. Logit Regression Analysis output

\begin{tabular}{|c|c|c|c|c|}
\hline \multicolumn{3}{|c|}{ Dependent Variable: FAILURE } & & \\
\hline \multicolumn{5}{|c|}{ Method: ML - Binary Logit (Newton-Raphson / Marquardt steps) } \\
\hline \multicolumn{5}{|c|}{ Date: $11 / 02 / 17$ Time: $14: 21$} \\
\hline \multicolumn{5}{|c|}{ Sample: 20132016} \\
\hline \multicolumn{5}{|c|}{ Included observations: 157} \\
\hline \multicolumn{5}{|c|}{ Convergence achieved after 9 iterations } \\
\hline \multicolumn{5}{|c|}{ Coefficient covariance computed using the Huber-White method } \\
\hline Variable & Coefficient & Std. Error & z-Statistic & Prob. \\
\hline LAD & 6.632 & 2.863 & 2.317 & 0.021 \\
\hline CAR & 4.429 & 14.466 & 0.306 & 0.759 \\
\hline AQ & 26.998 & 13.456 & 2.006 & 0.045 \\
\hline MQ & -9.760 & 2.995 & -3.259 & 0.001 \\
\hline ROE & 22.922 & 8.532 & 2.687 & 0.007 \\
\hline SM & -14.987 & 5.544 & -2.703 & 0.007 \\
\hline LOG(ASSETS) & -0.484 & 0.328 & -1.478 & 0.139 \\
\hline $\mathrm{C}$ & 0.974 & 7.354 & 0.132 & 0.895 \\
\hline McFadden R-squared & 0.327 & \multicolumn{2}{|c|}{ Mean dependent var. } & 0.045 \\
\hline S.D. dependent var. & 0.207 & \multicolumn{2}{|c|}{ S.E. of regression } & 0.189 \\
\hline Akaike info criterion & 0.347 & \multicolumn{2}{|c|}{ Sum squared resid } & 5.344 \\
\hline Schwarz criterion & 0.503 & \multicolumn{2}{|c|}{ Log likelihood } & -19.255 \\
\hline Hannan-Quinn criter. & 0.410 & \multicolumn{2}{|c|}{ Deviance } & 38.509 \\
\hline Restr. deviance & 57.228 & \multicolumn{2}{|c|}{ Restr. log likelihood } & -28.614 \\
\hline LR statistic & 18.719 & \multicolumn{2}{|c|}{ Avg. log likelihood } & -0.123 \\
\hline Prob(LR statistic) & 0.009 & & & \\
\hline Obs. with Dep. $=0$ & 150 & \multicolumn{2}{|c|}{ Total obs. } & 157 \\
\hline Obs. with Dep. $=1$ & 7 & & & \\
\hline
\end{tabular}

As shown in Table 2 the coefficient for liquidity risk or loans to deposit ratio (LAD) is 6.632, with $\mathrm{Z}$ statistics value of 2.317 and probability of 0.021 . Capital adequacy ratio (CAR) has a coefficient of 4.429 , Z-statistic of 0.306 and probability of 0.759 . Asset quality (AQ) has a coefficient of 26.998 , Z-statistic of 2.006 and probability of 0.045 . Management quality (MQ) has a coefficient of -9.760 , Z-statistic of -3.259 and probability of 0.001 . Earnings (ROE), has a coefficient of 22.922, Z-statistic of 2.687 and probability of 0.007 . Sensitivity to market has a coefficient of -14.987, Z-statistic of -2.703 and probability of 0.007 . The natural logarithm of total assets (LOG (ASSETS)) has a coefficient of -0.484 , Z-statistic of -1.478 and probability of 0.139 . The constant (C) has an insignificant coefficient of 0.974, Z-statistic of 0.132 and probability of 0.895 . Model statistics indicate that the McFadden R-squared of the regression is 0.327 , the likelihood ratio statistic is 18.719 with a probability of
0.009, deviance of 38.509 and restricted deviance of 57.228, Akaike information criterion of 0.347 and Schwartz criterion of 0.503 .

\section{Conclusions and Recommendation}

There exists a positive correlation between bank failure and liquidity risk, capital adequacy, asset quality, and earnings. This implies that increase in these variables increase the likelihood of bank failure. Similarly, a negative correlation between bank failure and management quality, sensitivity to market and bank size implies that increase in these variables decreases the likelihood of bank failure. A positive correlation between liquidity risk and capital adequacy, earnings, and sensitivity to market implies that as banks take more liquidity risk; capital adequacy, earnings and sensitivity to market tend to 
increase as well. On the other hand a negative correlation between liquidity risk and asset quality, management quality and bank size implies that as liquidity risk increases these variables tend to decrease. Spearman rank correlation also shows a positive correlation between capital adequacy and sensitivity to market which means that as capital adequacy increases so does sensitivity to market increase. Conversely, a negative correlation between capital adequacy and asset quality, management quality, earnings and size implies that as capital adequacy increases these variables also decrease. Similarly, a positive correlation between asset quality and management quality indicates as one of these variables increase so does the other. On the contrary a negative correlation between asset quality and earnings, sensitivity to market and bank size indicates that as asset quality (or nonperforming loans) increases earnings, sensitivity to market and size deceases as well.

Spearman rank correlation also shows a negative correlation between management quality and earnings, sensitivity to market and bank size implying that as management quality or operational costs increase earnings, sensitivity to market and bank size decrease. A positive correlation between earnings and sensitivity to market and bank size implies that as earnings increase sensitivity to market and bank size also increase. Finally, a positive correlation between sensitivity to market and bank size means that as sensitivity to market increases bank size increases.

The fact that liquidity risk has a positive coefficient implies that increase in liquidity increases the likelihood of failure. According to Zheng et al. [17] the relationship between liquidity risk and bank failure can be negative if failed banks suffer from the moral hazard problem or positive if the banks are pursuing the precautionary motive of the liquidity preference theory. The fact that the coefficient is positive and significant at $95 \%$ confidence level indicates that failed banks had stocked piled liquid asset for precautionary reasons. This finding is contrary to Canicio and Blessing [27] who found liquidity to be significant and negatively correlated with bank crisis or failure. The finding is however consistent with the findings of Sahut and Mili [28] and Pena [29] who found liquidity to be positively correlated with banking crisis, and Zheng et al. [17] who found a positive correlation between failure of small banks and liquidity risk. The finding is also consistent with Berger and Bouwman [15] who through trend analysis found that liquidity creation tends to be higher prior to financial crisis. Given that the banks that failed in Kenya were small banks, this finding is considered valid.

Capital adequacy has a positive coefficient implying that increase in equity in the capital structure of banks increases the likelihood of bank failure. The positive sign is inconsistent with the findings Canicio and Blessing [27]; Sahut and Mili [28] and Zheng et al. [17] who found capital adequacy to be significant and negatively correlated with failure. However, the insignificant probability implies that the capital adequacy has no significant effect on bank failure.

Asset quality has a positive coefficient indicating that it increases the likelihood of failure. Since the Z-statistic is more than 1.96 and the p-value is below 0.05 then asset quality has a significant influence on bank failure. This finding confirms previous empirical studies like Zheng et al. [17] and Canicio and Blessing [9] who found it both positive and significant. Management quality has a negative coefficient implying that it decreases the likelihood of bank failure. Nonetheless, its p-value of less than 0.05 signifies that it has significant relationship with bank failure. This finding is contrary to the results of Zheng et al. [17] and Canicio and Blessing [27]). Earnings, measured by (ROE) have a positive coefficient implying that increase in profitability increases the likelihood of failure. The fact that the $p$-value of earnings is less 0.05 indicates that profitability has a significant relationship with failure. This finding is inconsistent with the finding of Zheng et al. [17] and Canicio and Blessing [27]. Sensitivity to market has a negative coefficient implying that having more securities decreases the likelihood of bank failure. The natural logarithm of total assets has negative coefficient implying that increase in size reduces the likelihood of bank failure. The negative coefficient compares well with previous studies like Sahut and Mili [28] and Zheng et al. [17].

\subsection{Conclusions}

The study found a positive and significant relationship between liquidity risk and bank failure. According Zheng et al. [17] appositive relationship between liquidity risk and bank failure confirms that failed bank had pursued the precautionary motive of the liquidity preference theory. Earnings had a significant positive relationship with bank failure indicating that banks that failed were making profit prior to their failure. This indicates that bank managers need to understand the negative effect of pursuing short term profit as the main goal instead of pursuing shareholder wealth maximization as discussed in the theory of the firm by Jensen and Meckling [30].A positive and significant relationship between bank failure and earnings provides empirical support that bank managers of failed banks had not pursued shareholders wealth maximization as the main goal of the firm but had rather sought to maximize short-term profits. This leads to the conclusion that just as making losses can lead to bank failure through bankruptcy risk, excess profits can equally cause bank failure through excessive loans default risk. The study's regression results show that sensitivity to market had significant negative relationship with bank failures, implying that holding more securities reduced the likelihood of bank failure. Bank should therefore have more liquid securities to reduce their chances of failure. The fact that both earnings and asset 
quality had a significant positive coefficient implying that the two variables increased the likelihood of bank failure indicates that moral hazard problem played a major role in the failure of commercial banks in Kenya.

The regression however did not find a significant relationship between bank failure and capital adequacy and bank size. This implies that the banks that failed suffered their predicaments mainly for the way they managed their business and not on size and capitalization. Since capital adequacy was an insignificant variable in the regression, then we can infer that failed banks were not insolvent at the time of failure.

\subsection{Recommendations}

Given that the liquidity risk, asset quality, management quality, earnings and sensitivity to market showed a significant relationship with bank failure, the study recommends that bank managers emphasize on this variables in their day to day management practices. Further, given that the coefficient of earning is positive implying that profitability increased the likelihood of bank failure, the study suggest that managers of banks should be risk sensitive instead of endeavouring to make short-term profits that increase the chances of bank failure. Further, Since liquidity risk has been identified a significant factor related to bank failure the study recommends that the central bank of Kenya implements the Basel III accord to enhance a more detailed reporting on liquidity especially the liquidity coverage ratio (LCR) and the net stable funding ratio (NSFR).

Since asset quality has been found to have a significant relationship with failure of commercial banks in Kenya, this may be an indication of weakness in the credit standards used to screen borrowers. The study recommends that bank managers reassess their current credit standards and consider replacing them with more comprehensive standards. These new and comprehensive credit standards will reduce nonperforming loans and save banks from impending failures. Further as management quality has a negative and significant relationship with failure of commercial banks. The study recommends that banks should study and find an optimal level of operating expenses that can help in reducing the likelihood of failure.

\subsection{Limitations of the Study}

The main limitation of the study was that it relied on observations spanning over the four years 2013 to 2016 and hence likely to suffer from the small sample bias. This limitation was overcome by doing a census study that incorporated all commercial banks in Kenya. The study was also limited by the fact that at the time of the study the websites of all failed banks were closed hence limiting the availability of financial statements in a timely manner. This limitation was overcome by searching for the financial statement in past newspapers. Further annual reports of one the failed banks for the year 2015 were not incorporated in the analysis for lack of integrity as the auditors had qualified it. A further limitation of the study is that it was designed to be a descriptive investigation. As such even if the study found significant relationships between bank failure and LAMES no conclusion can be made that these variables were indeed cause of bank failure. This means that to establish the causality of the variables another study need to be done with the objective of finding the causes of bank failures. Nonetheless, the relationship of bank failure with macroeconomic variables like inflation, unemployment, interest rate and gross domestic product growth rate were not investigated in this study. Since empirical studies show that these factors can contribute to bank failure, these factors are left for future studies.

\subsection{Suggestions for Further Research}

Since the study relied on annual financial statements, it is suggested that the study be replicated with biannual or quarterly financial to capture the effects of the CAMELS on bank failure more proximately. The study concentrated on a narrow window of only four years. The study makes suggestion that a study covering all previous bank failures be done because it might yield more insightful results than those found by this study. A further suggestion is that detailed case studies of each failed bank be carried out to delve into factors that prompted failure of commercial banks in Kenya beyond the CAMELS factors.

The study suggests that a sequel study be carried out to establish whether the relationships shown in this study were also causal in nature or not. It is suggested that a study be carried out that will control for the effect of distressed banks on the relationship between bank failure and the independent variables. Finally this study was retrospective in nature. It is suggested that a prospective study predicting or forecasting bank failures in Kenya be carried out to complement the findings of this study and to provide proactive managerial action.

\section{REFERENCES}

[1] Heffernan, S. (2005). Modern banking (1st ed.). West Sussex, England: John Wiley \& Sons Ltd

[2] Kumar, M. \& Yadav, G. (2013). Liquidity Management in Bank: A conceptual framework. AIMA Journal of Management \& Research, 2(4), 974-997.

[3] Kaufman, G. G. (1996). Bank failures, systemic risk, and bank regulation. Cato Journal., 16(17).

[4] Daley, J., Matthews, K., \& Whitfield, K. (2008). Too-big-to-fail: Bank failure and banking policy in Jamaica. Journal of International Financial Markets, Institutions and Money, 18(3), 290-303. 
[5] Minamihashi, N. (2011). Credit Crunch Caused by Bank Failures and Self - Selection Behaviour in Lending Markets. Journal of Money, Credit and Banking, 43(1), 133-161.

[6] Bennett, L. R. \& Unal, H. (2015). Understanding the Components of Bank Failure Resolution Costs. New York University Salomon Center and Wiley Periodicals, Inc24 (5), 349-389.

[7] Banks, E. (2005). Liquidity Risk: Managing Asset and Funding Risk. New York: Palgrave Macmillan.

[8] Farag, M., Harland, D., \& Nixon, D. (2013). Bank capital and liquidity. Bank of England Quarterly Bulletin 2013 Q3, 201-215.

[9] Gomes, T., \& Khan, N. (2011). Strengthening bank management of liquidity risk: The Basel III liquidity standards. Bank of Canada Financial System Review, 5, $35-42$.

[10] Diamond, D., \& Dybvig, P. (1983). Bank Runs, Deposit Insurance, and Liquidity. Journal of Political Economy, 91(3), 401-419.

[11] Acerbi, C. \& Scandolo, G., (2008). Liquidity risk theory and coherent measures of risk. Quantitative Finance, 8(7), 681-692.

[12] Cucinelli, D. (2013). The Relationship between Liquidity Risk and Probability of Default: Evidence from the Euro Area. Risk Governance \& Control: Financial Markets \& Institutions, 3(1), 42-50.

[13] Ogilo, F., \& Mugenyah, L. O. (2015). Determinants of Liquidity Risk of Commercial Banks in Kenya. The International Journal of Business \& Management, 3(9), 469-473.

[14] Wekesa, N. R., (2016). The relationship between liquidity risk and financial performance of commercial banks in Kenya (Master of Finance thesis University of Nairobi.)

[15] Berger, A. N., \& Bouwman, C. H. (2009). Bank liquidity creation. The Review of Financial Studies, 22(9), 3779-3837.

[16] Fungacova, Z., Turk, R., \& Weill, L. (2015). High liquidity creation and bank failures (No. 15-103). International Monetary Fund.

[17] Zheng, C., Cheung, A., \& Cronje, T. (2016, December). Bank Liquidity, Bank Failure Risk and Bank Size. In ECU Business Doctoral and Emerging Scholars Colloquium
2016 (p. 38).

[18] Kaufman, G. G. (1996). Bank failures, systemic risk, and bank regulation. Cato Journal., 16(17).

[19] Okeahalam, C. C. (1998). The political economy of bank failure and supervision in the Republic of South Africa. African Journal of Political Science/Revue Africaine de Science Politique, 29-48.

[20] Minamihashi, N. (2011). Credit Crunch Caused by Bank Failures and Self - Selection Behaviour in Lending Markets. Journal of Money, Credit and Banking, 43(1), 133-161.

[21] Müller, J. \& Trümpler, K., (2004). Financial Contagion. Retrieved from: http://www.hec.unil.ch/pstamour/enseignement/Lausanne/ Pol_Macro/papiers/groupe_7.pdf

[22] Macey, J., \& Miller, G. (1988). Bank Failures, Risk Monitoring, and the Market for Bank Control. Columbia Law Review, 88(6), 1153-1226.

[23] James, C. (1991). The Losses Realized in Bank Failures. The Journal of Finance, 46(4), 1223-1242.

[24] Bouvatier, V., Brei, M., \& Yang, X. (2013). The determinants of bank failures in United States: Revised. BIS Working Paper No. 357, 26.

[25] Skrivanek, S. (2009). The use of dummy variables in regression analysis. More Steam, LLC.

[26] Central Bank of Kenya, (2012).Bank Supervision Annual Report 2012. Retrieved from: www.centralbank.go.ke.

[27] Canicio, D. \& Blessing, K. (2014). Determinants of Bank Failures in Multiple-Currency Regime in Zimbabwe (20092012). International Journal of Economics and Finance, 6(8), 229-246.

[28] Sahut, M. J. \& Mili M. (2011). Determinants of Banking Distress and Merger as Strategic Policy to Resolve Distress. Economic Modelling, 28(1/2), 138-146.

[29] Pena, G. (2016). The determinants of Banking Crises: Further Evidence (MPRA paper 70093). Munich Personal RePEc Archive (MPRA). Retrieved from: https://mpra.ub.uni-muenchen.de/70093/1/MPRA_paper_7 0093.pdf.

[30] Jensen, C. M. \& Meckling, H. W. (1976). Theory of the Firm: Managerial Behaviour, Agency Costs and Ownership Structure. Journal of Financial Economics, 3(4), 305-360. 